\author{
Available online at JECE (Journal of Early Childhood Education) \\ Website: http://journal.uinjkt.ac.id/index.php/jece \\ Permalink/DOI: http://dx.doi.org/10.15408/jece.v3i1.19059 \\ JECE, 3 (1), Juni 2021, 22-30
}

\title{
PLAYING ORIGAMI DAN ITS IMPACT ON FINE MOTOR SKILLS DEVELOPMENT OF CHILDREN AGED 4-5
}

\author{
Aghnia Nur Anisa, Ulwan Syafrudin, Rizky Drupadi \\ Universitas Lampung, Indonesia \\ Corresponding e-mail: aghnianaa@gmail.com
}

\begin{abstract}
This study aims to determine the effect of origami activities on the fine motor skills of children aged 4-5 years. This research is using an experimental design. This research was conducted in the CABI Tanggamus learning group, which was conducted on fifteen children using a one-group pre-test post-test design. Data collection techniques used in this study are observation and documentation. In this study, the pre-test results of children's motor skills were included in the Starting to Develop (MB) category, meaning the child obtained an average score of 26 from a maximum score of 72 . After the treatment, fine motor skills were included in Developing as Expected (BSH). The results obtained after treatment showed a score of 58 from a maximum score of 72 . The results of this study can be concluded that origami play activities can affect the fine motor skills of early childhood, which means that origami games provide changes in children's fine motor development. Based on the results of the study, the researcher recommends origami games to improve fine motor skills.
\end{abstract}

Keywords: Fine Motor Skill, Origami, Early Childhood

\begin{abstract}
Abstrak
Penelitian ini bertujuan untuk mengetahui pengaruh aktivitas origami terhadap kemampuan motorik halus anak usia 4-5 tahun. Penelitian ini menggunakan metode eksperimen. Penelitian ini dilakukan di kelompok Les CABI Tanggamus yang dilakukan terhadap lima belas anak dengan menggunakan desain one group pre-test post-test design. Teknik pengumpulan data yang digunakan dalam penelitian ini yaitu observasi dan dokumentasi. Pada penelitian ini menunjukan hasil pre-test kemampuan motorik anak termasuk dalam kategori mulai berkembang (MB) yaitu anak memperoleh skor rata-rata 26 dari skor maksimal 72. Setelah dilakukan perlakuan kemampuan motorik halus termasuk dalam kategori Berkembang Sesuai Harapan (BSH). Hasil yang diperoleh setelah treatment menunjukan skor 58 dari sekor maksimal 72. Hasil penelitian ini dapat disimpulkan bahwa aktivitas bermain origami dapat berpengaruh terhadap kemampuan motorik halus anak usia dini yang artinya permainan origami memberikan perubahan dalam perkembangan motorik halus anak. Berdasarkan hasil penelitian tersebut, peneliti merekomendasikan permainan origami untuk meningkatkan kemampuan motorik halus.
\end{abstract}

Kata Kunci: Motorik halus, Origami, Anak Usia Dini 


\section{Introduction}

Fine motor skills are one of the motor developments that must be optimized because they support many other developments in children (Huda, Faeruz, \& Hayati, 2019). Children will need maturity of children's fine motor development in the future, such as when children have daily activities, such as attaching buttons to clothes, eating, playing, and others (Dewi \& Surani, 2018). This skill can be achieved by maturing the central nervous system and specific motor experiences (Dehghan, Mirzakhani, Rezaee, \& Tabatabaee, 2017).

According to Sunani, fine motor skills involve small muscles, such as the ability to use fingers and wrists that are fixed. Santrock also said that fine motor skills use media with eye and hand coordination (Cllaudia, Wdiastuti, \& Kurniawan, 2018). From the above opinion, it can be concluded that fine motor skills use the muscles of the fingers and wrist movements using hand-eye coordination. The ability of children at each age is different. Children aged 4-5 years have fine motor skills, including eye and hand coordination, wrist flexibility, and finger strength and flexibility (Kemendikbud, 2015). Examples include tying shoelaces, putting letters in envelopes, forming things out of paper or clay, washing and drying their face without getting their clothes wet, threading threads through the eye of a needle (Putra, 2017).

Meanwhile, children aged 5-6 years have fine motor skills such as holding scissors, pencils and sticking. At this age, children can trace geometry, cut with scissors, print, and do activities that refer to better hand skills (Oktarina, Angraini, \& Susilawati, 2020). This fine motor development takes longer than gross motor skills because it requires more complex skills such as concentration, control, and caution (Yuliana \& Bahri, 2019).

The World Health Organization (WHO) reports that 5-25\% of preschool-aged children suffer from minor brain dysfunction, including impaired fine motor development. Preschool children are children aged 4-6 years. The occurrence of disturbances in children that causes inhibition of fine motor development will affect further growth, which can have long-term consequences for children (Sriwahyuni, Sulastri, \& Patabang, 2020). Reduced fine motor development means that fine motor development is below the standard level of child development achievement. As a result, children cannot perform developmental tasks that are appropriate for their age group at a certain age. Danger causes delayed motor development, some can be controlled, and some are not. The delay is often caused by the child's lack of opportunity to learn motor skills, excessive parental protection, lack of motivation to learn it, and lack of stimulation (munawaroh, nurwijayawati, 2019). 
Teachers can make various efforts to overcome some of the delicate motor problems experienced by children. Such as developing children's fine motor skills with various activities that train children's fine motor skills such as rolling, sticking, and playing with Lego, but these activities are monotonous. Hence, children tend to get bored because they do fine motor activities that are often done. Fun learning and a variety of media can develop fine motor skills (Ikho Elista Liana, M. Kristanto, 2017). So, to stimulate children's motor development through various exciting activities, children will feel challenged to do it perfectly with exciting activities. One way is to provide directed stimulation through games, one of which is the origami paper folding game (Sriwahyuni et al., 2020)

Folding is an activity that can develop fine motor skills. Fine motor movements through folding activities are movements that involve specific body parts carried out by tiny muscles. Fine motor movements do not require much energy but require careful coordination and accuracy (Aeni \& Christiana, 2016). Based on research conducted by Qomariyah and Khotimah, folding activities can increase fine motor skills by $43 \%$ (Qomariyah \& Khotimah, 2016).

Folding activities can use various media, one of which is using origami paper. According to Sao Honda, origami is the art of folding paper from Japan to make something shaped like insects, flowers, and others produced from this origami art (Sriwahyuni et al., 2020). Another opinion says origami is a handicraft technique made from paper to produce toys, decorations, functional objects, props, and other creations (Sumanto, 2006). In short, origami, or paper folding, is a folding activity by making shapes and various crafts (Tiasari \& Ashshidiqi, 2020). Playing origami can improve children's physical motor development and develop children's social skills. Children whose motor development is less than optimal will make children less selfrespect and not confidence. However, through playing origami, it is hoped that their motor development can develop optimally, so that children feel more confident in front of their friends (Wiryaningsih, Jampel, \& Antara, 2016). The role of origami can extend to all fields, for example, used as part of living equipment. Origami has entered all aspects of human life. Thus, origami has a role in all fields depending on human needs, including its role in the field of education to train fine motor skills in a lesson (Faizatin, 2018). Folding activities have many benefits; besides stimulating children's fine motor skills, they can also stimulate children's cognitive, especially introducing creativity, mathematical concepts, and construction, fostering independence, children's self-confidence (Widayati, Simatupang, Aprianti, \& Maulidiya, 2020). According to Oguz (2016), origami can contribute to developing motor skills, intellectuals, and creativity of preschool and elementary school-age children (Dina Puspitasari, Ari sofia, 2019). Based on the explanation above, the researcher aims to find out how influential the origami game is on the fine motor skills of children aged 4-5 years in this study. This study carried out origami folding 
activities through various stages, from folding with instructions to folding according to one's own creation. So that in addition to fine motor skills, children can develop well, it is hoped that children's creativity can also develop well.

\section{Method}

Research conducted using quantitative research using experimental methods. The experimental research method is a method or way to find a causal relationship between two factors that researchers intentionally cause by eliminating or reducing, or setting aside other factors that interfere (Arikunto, 2006). This study uses a onegroup pre-test post-test design, which is a research design that examines one group before by taking one measurement before the treatment and once after the treatment. The research design that will be used in this study is described as follows:

\section{$\mathrm{O}_{1} \mathrm{X} \mathrm{O}_{2}$}

Design of One Group Pre-test and Post-test (N. Dantes, 2017)

$\mathrm{O}_{1} \quad$ : Pre-test scores (before treatment)

$\mathrm{X} \quad$ : Treatment (Treatment through origami playing activities)

$\mathrm{O}_{2} \quad$ : Post-test scores (After treatment)

The subjects in this study were 15 children aged 5-6 years who were taking Les Cabi, Tanggamus, Lampung, consisting of 12 girls and three boys. Data collection techniques used in this study are observation and documentation. The type of observation used is non-participant observation, where the researcher is not involved in learning activities and only focuses on the treatment and the treatment results. At the same time, the documentation is taking photos of children's activities during the pre-test, treatment, and post-test. Observation guidelines are used in the form of a checklist with the categories of Undeveloped (BB), Starting to Develop (MB), Developing as Expected (BSH), Well Developing (BSB).

\section{Results and Discussion}

This research was conducted in 3 stages, including pre-test (before treatment), treatment (treatment), and post-test (after treatment). The assessment used is an indicator assessment with 18 points of achievement indicators and four Likert scales. The pre-test results showed that the children's fine motor skills in the folding paper were included in the still-developing category. It is obtained an average score of 26 from a maximum score of 72 . In the Undeveloped category (BB), 73\% with a frequency of 11, Starting to Develop (MB) $27 \%$ with 4.

Vol. 3 No. $1 \mid 25-30$ 
Table 1. The Overview of Fine motor skills before treatment (Pre-test)

\begin{tabular}{lllll}
\hline No & Category & Score Range & Frequency & Description (\%) \\
\hline 1 & Undeveloped (BB) & $18-31$ & 11 & $73 \%$ \\
\hline 2 & Starting to Develop (MB) & $32-45$ & 4 & $27 \%$ \\
\hline 3 & Developing as Expected (BSH) & $46-59$ & 0 & $0 \%$ \\
\hline 4 & Well Developing (BSB) & $60-72$ & 0 & $0 \%$ \\
\hline \multicolumn{2}{r}{ Total } & Average: 26 & 15 & $100 \%$ \\
\hline
\end{tabular}

After the pre-test results are known, then treatment or treatment is carried out using origami paper. This treatment was carried out in 4 meetings. Children are given instructions to fold origami into a fish shape on the first day by following the steps shown. On the second day, the children were asked to fold the paper and were given several steps to make shapes, and the children were allowed to choose what they would make. On the third day, the children were given origami paper and invited to make anything according to their creativity. On the fourth day, the treatment is the same as the third day.

After the treatment activities are completed, post-test activities are carried out. The activities carried out are the same as those during the pre-test, namely making folds using origami paper. The post-test theme is transportation. The results obtained after treatment showed a score of 58 out of a maximum score of 72 . Furthermore, the category for one child is Starting to Develop (MB) with $6.67 \%$; 6 children are Developing as Expected (BSH) with $40 \%$, and eight children are Well Developing (BSB) with $53.3 \%$. So, it can be concluded that children's fine motor skills in the Les $\mathrm{CABI}$ group, Tanggamus, are in the category of Developing as Expected (BSH).

Table 2. The Overview of Fine motor skills after treatment (Post-test)

\begin{tabular}{lllll}
\hline No & Category & Score Range & Frequency & Description (\%) \\
\hline 1 & Undeveloped (BB) & $18-31$ & 0 & $0 \%$ \\
\hline 2 & Starting to Develop (MB) & $32-45$ & 1 & $6,67 \%$ \\
\hline 3 & Developing as Expected (BSH) & $46-59$ & 6 & $40 \%$ \\
\hline 4 & Well Developing (BSB) & $60-72$ & 8 & $53,3 \%$ \\
\hline \multicolumn{2}{r}{ Total } & Average: 58 & 15 & $100 \%$ \\
\hline
\end{tabular}

Based on the table above, it can be seen that the children's motor skills after being given treatment did not find children who were in the undeveloped category. Unlike before the treatment, there were still 11 children who were in the undeveloped category. After treatment, only one child was found in the category of starting to develop. The rest were in the category of developing according to the expectations of 6 children, and eight children developing very well. It shows a change in the level of good development in the fine motor aspects of children, 
namely from before treatment to after treatment. Fine motor development is moving in control, coordination, and dexterity to use the fingers (Pangesti, Wahyuningsih, \& Dewi, 2019).

In contrast, origami comes from the Japanese language, which means folding paper. Origami has many benefits, including giving positive stimulants to children's brains, training fine motor skills, and training children's accuracy and tidiness (Eng, 2005)(Hasanah \& Priyanto, 2019). For children who often do folding activities, the movements of their fingers become more well stimulated so that the child's motor skills become better. According to the research above, through origami activities, many children whose initial developmental scale has not yet developed fine motor skills rise to the above scale, starting to develop, developing according to expectations, or developing very well. So it can be seen that origami playing activities can affect the fine motor skills of early childhood, which means that origami games change children's fine motor development.

It is in line with Cllaudia (2018) research, which says that origami games can improve children's fine motor skills by $79.62 \%$. Besides, origami games can also train hand and eye coordination (Cllaudia et al., 2018). Diana, in her research, also said that one of the benefits of origami is to improve children's fine motor skills (Diana, 2015). Playing origami is an activity that involves elements of muscles, nerves, brain, and fingers. Children should be given motivation, encouragement that can raise children's interest in these activities. Children are trained to hold the paper correctly when folding a paper in a particular shape to increase the flexibility of the child's fingers. It is where these elements will be coordinated if done intensively (Widiyawati, 2020). In addition, origami paper folding activities are also included in sensory-motor play activities, which require complex hand movements so that children can hold pencils, imitate making letters or numbers, draw, and so on. During the research, it was seen that the children felt happy and were always curious about each shape that would be made on that day because every day, the researcher gave different origami shapes. (Shely Nur Kusuma, Thoha Sampurna, \& Gian Fitria, 2018). At the age of 4 years, children's coordination of fine motor movements is very developed, even almost perfect. At the age of 5 or 6 years, the coordination of fine motor movements is developing rapidly. At this time, the child can coordinate visual motor movements, such as coordinating eye movements with the hands, arms, and body simultaneously, among others, can be seen when the child is writing or drawing (Sujarwo \& Widi, 2015). It also proves that folding paper is one of the main features of self-corrective shaping exercises, in the sense that children know for themselves if they form or fold the folded paper incorrectly. And children will always explore with trial and error activities to find new findings based on their own experiences (Rahmawati \& Khotimah, 2013) 


\section{Conclusion}

Fine motor skills are fundamental. With fine motor skills, children can develop various skills, such as writing, drawing, coloring, sewing, or making a craft, along with the many mastery of fine motor skills possessed by children. The better the children's achievement in school because fine motor skills are needed in academic activities almost all day. Fine motor development must be done in a fun way for children, one of which is through origami play activities. From the research results conducted in the Les CABI group, it was found that origami can improve children's fine motor skills. Therefore, researchers recommend providing folding activities using this origami, one form of activity used to stimulate children's fine motor development.

\section{References}

Aeni, Q., \& Christiana, E. (2016). Pengaruh Kegiatan Origami Terhadap Keterampilan Motorik Halus Pada Anak Kelompok B. PAUD Teratai, 5(2), 1-4.

Arikunto. (2006). Metode Penelitian Kuantitatif. Jakarta: Bumi Aksara.

Cllaudia, E. S., Wdiastuti, A. A., \& Kurniawan, M. (2018). Origami Game for Improving Fine Motor Skills for Children 4-5 Years Old in Gang Buaya Village in Salatiga. Jurnal Obsesi: Jurnal Pendidikan Anak Usia Dini, 2(2), 143. https://doi.org/10.31004/obsesi.v2i2.97

Dehghan, L., Mirzakhani, N., Rezaee, M., \& Tabatabaee, M. (2017). The relationship between fine motor skills and social development and maturation. Iranian Rehabilitation Journal, 15(4), 407-414. https:/ / doi.org/10.29252/nrip.irj.15.4.407

Dewi, N. K., \& Surani, S. (2018). Stimulasi Kemampuan Motorik Halus Anak Usia 4-5 Tahun Melalui Kegiatan Seni Rupa. Jurnal Pendidikan Anak, 7(2), 190-195. https://doi.org/10.21831/jpa.v7i2.26333

Diana, S. (2015). Pengaruh Permainan Origami Terhadap Perkembangan Motorik Halus Pada Anak Paud Umur 3-4 Tahun Di TK AL- Kholifa Desa Seloroja Kec. Mojowarno Kab. Jombang. Health Sciences Journal. 1(2), 1, 102.

Dina Puspitasari, Ari sofia, G. F. A. (2019). Pengaruh Kegiatan Bermain Origami Terhadap Kemampuan Motorik Halus Anak Usia Dini. Jurnal Pendidikan Anak, $5(1)$.

Eng, T. S. (2005). A review of the impact of ICT on learning. International Education Journal, 6(5), 635-650. Retrieved from http:/ /ftp.jrc.es/EURdoc/JRC47246.TN.pdf\%5Cnfile:/ / Users/udv/Dropbox/ Tesis hipervi?deo/Bibliografi?a/Library.papers3/Files/EC/ECD3DDA8-696E4716-A6EB-2C1B0571720A/ECD3DDA8-696E-4716-A6EB2C1B0571720A.pdf\%5Cnpapers3:/ / publication/uuid/ A2026276-3AAE- 
Faizatin, N. (2018). Peningkatan Motorik Halus Melalui Kegiatan Origami Pada Anak Kelompok A TK DWP Kedungrukem Benjeng Gresik Tahun Pelajaran 2015/2016. Pedagogi: Jurnal Anak Usia Dini Dan Pendidikan Anak Usia Dini, 4(2), 80. https://doi.org/10.30651/pedagogi.v4i2.1964

Hasanah, U., \& Priyanto, D. E. (2019). Pengembangan Kreativitas Anak Usia Dini Melalui Origami. Ele, 5(1), 61-72. https:/ / doi.org/10.52185/kariman.v7i2.118

Huda, H., Faeruz, R., \& Hayati, M. (2019). PERMAINAN KOLASE UNTUK MENINGKATKAN MOTORIK HALUS PADA KELOMPOK A TK MUSLIMAT NU BANJARMASIN. Journal of Early Childhood Education (JECE), 1(2), 1-8. https://doi.org/10.15408/jece.v1i2.13278

Ikho Elista Liana, M. Kristanto, I. K. (2017). Upaya Meningkatkan MotorikHalus Anak melalui Kegiatan Origami Variatif pada Kelompok A Usia 4-5 Tahun di KB-TK Daqu School Semarang. Journal of Materials Processing Technology, 1(1), 18. Retrieved from http:/ / dx.doi.org/10.1016/j.cirp.2016.06.001\%0Ahttp://dx.doi.org/10.1016/j.p owtec.2016.12.055\%0Ahttps://doi.org/10.1016/j.ijfatigue.2019.02.006\%0Ahttps: / / doi.org/10.1016/j.matlet.2019.04.024\%0Ahttps://doi.org/10.1016/j.matlet.20 19.127252\%0Ahttp://dx.doi.o

munawaroh, nurwijayawati, I. (2019). Gambaran Perkembangan Motorik Halus Pada Anak Usia Prasekolah Dengan Metode Menggambar. Community of Publishing in Nursing (COPING), hlm. 54.

N. Dantes. (2017). Desain Eksperimen dan Analisis Data. Depok: Rajawali pers.

Oktarina, A., Angraini, W., \& Susilawati, B. (2020). Penggunaan Media Kolase dalam Mengembangkan Ketrampilan Motorik Halus Anak Usia 5-6 Tahun. Jurnal Ilmiah Pendidikan Anak Usia Dini, 3(2), 186-198.

Pangesti, N. P., Wahyuningsih, S., \& Dewi, N. K. (2019). Jurnal Kumara Cendekia PENDAHULUAN Terdapat enam aspek Hasil tes pratindakan dilakukan dengan tes menggunakan unjuk kerja, terdapat indikator anak belum mampu motorik dalam halus perkembangan anak usia dini yang harus dikembangakan perkembangan salah sat. Kumara Cendekia, 7(4).

Putra, M. R. (2017). Peningkatan Kemampuan Motorik Halus Anak Usia 5-6 Tahun melalui Kegiatan Menggunting Terbimbing di PAUD Al Fatih Kota Lubuklinggau Tahun 2017. Jurnal Ilmiah Kajian Ilmu Anak Dan Media Informasi PAUD, 2(1), 50-55.

Qomariyah, S., \& Khotimah, N. (2016). Meningkatkan kemampuan Motorik Halus Melalui Kegiatan Melipat pada Anak Kelompok A. Jurnal PAUD Teratai, 5, 97. Retrieved from https://ejournal.upi.edu/index.php/agapedia/article/download/30454/13520 
Rahmawati, I., \& Khotimah, N. (2013). Meningkatkan Motorik Halus Anak Dengan Melipat Kertas Sederhana kelompok B TK Pertiwi I Balongbesuk Kecamatan Diwek Kabupaten Jombang Tahun. Jurnal Mahasiswa Teknologi. Retrieved from http:/ / ejournal.unesa.ac.id/article/5888/19/article.pdf

Shely Nur Kusuma, N., Thoha Sampurna, J., \& Gian Fitria, A. (2018). Kegiatan Menggunting Kertas Kirigami Meningkatkan Pekembangan Motorik Halus Anak Usia Dini. Jurnal Pendidikan Anak FKIP Universitas Lampung.

Sriwahyuni, Sulastri, \& Patabang, I. (2020). Efektivitas Pemberian Alat Permainan Edukatif Origami Terhadap Perkembangan Motorik Halus Anak Di TK Frater Bakti Luhur Makassar. Jurnal Ilmiah Kesehatan Pencerah, 09(1), 59-64. Retrieved from https:/ / stikesmu-sidrap.e-journal.id/JIKP

Sujarwo, \& Widi, C. P. (2015). Kemampuan Motorik Kasar dan Halus Anak Usia 4-6 Tahun. Jurnal Pendidikan Jasmani Indonesia, 11(2), 96-100. Retrieved from https://journal.uny.ac.id/index.php/jpji/article/view/8185/6856

Sumanto. (2006). Pengembangan Kreativitas Seni Rupa Anak TK. Jakarta: Direktorat Jendral Pendidikan Tenaga Kependidikan dan Tenaga Perguruan Tinggi.

Tiasari, N. A., \& Ashshidiqi, A. (2020). Penerapan Kegiatan Origami Dalam Mengembangkan Motorik Halus Anak Usia 5-6 Tahun. 5(1), 39-43. Retrieved from http:/ /jurnal.upmk.ac.id

Widayati, S., Simatupang, N. D., Aprianti, A., \& Maulidiya, R. (2020). Kegiatan Melipat Kertas Lipat Bermotif untuk Meningkatkan Kemampuan Motorik Halus Anak. Al-Athfaal: Jurnal Ilmiah Pendidikan Anak Usia Dini, 3(1), 30-44. https://doi.org/10.24042/ajipaud.v3i1.6544

Widiyawati, J. (2020). Kegiatan Bermain Origami dalam Mengembangkan Ketrampilan Motorik Halus Anak Usia Dini di Raudhotul Athfal Al -Akhyar Bungo (UNIVERSITAS ISLAM NEGERI SULTHAN THAHA SAIFUDDIN JAMBI). Retrieved from https://online210.psych.wisc.edu/wpcontent/uploads/PSY-210_Unit_Materials/PSY-

210_Unit01_Materials/Frost_Blog_2020.pdf\%0Ahttps://www.economist.com/s pecial-report/2020/02/06/china-is-making-substantial-investment-in-portsand-pipelines-worldwide\%0Ahttp:/ /

Wiryaningsih, N. K. S. A., Jampel, I. N., \& Antara, P. A. (2016). Penerapan Kegiatan Melipat Kertas Origami Untuk Meningkatkan Kemampuan Motorik Halus Pada Anak TK Aisyiysh Bustanul Athfal. E-Journal Pendidikan Anak Usia Dini Universitas Pendidikan Ganesha Jurusan Pendidikan Guru Pendidikan Anak Usia Dini, $4(2)$.

Yuliana, D., \& Bahri, S. (2019). Kemampuan Motorik Halus Anak Usia 4-5 Tahun Melalui Model Pembelajaran Sentra Alam Di PAUD (Kober) Bintang Kecil. Ceria Jurnal Pendidikan Anak Usia Dini, 10(1), 54-64. 